AÜiFD XLVI (2005), sayı II, s. 13-42

\title{
İnsanın Yetkinliğini Teolojik Olarak Temellendirmenin İmkanı
}

ŞABAN ALİ DÜZGÜN

Prof.Dr., ANKARA Ü. İLÂHIYAT FAKÜLTESI

e-mail: duzgun@divinity.ankara.edu.tr

\begin{abstract}
The Possibility of Demonstrating Human Capability Theologically The reason why God created world (final cause), beyond doubt, was humanity. Just as God has necessary attributes to rule the world, so do human kinds to lead their lives on earth. God entrusted the world to human beings' care and to make this viable He provided them with ontic and epistemic disposition, which are underscored in the Holy Qur'an as fitra and hidaya. This paper provides vital Qur'anic concepts which are used to prove human capability of laying values for his own life by relying both his reason and experience and interpreting the Holy Qur'an accordingly.
\end{abstract}

key words

Humanity, Fitra, Hidaya, Individual, Person, Conceptual Evolution of Holy Books.

\section{Kur'an'ın Temel Insan Tasavvuru}

1. Insanın Ontik Yapısı

a. Beşer ve Insan

Kur'an insanı iki seviyede ele almaktadır: Bunlardan ilki, insanın maddi varlık yapısını karşılayan beşer, diğeri ise bu maddi yapıyı anlamlı kılan ruhsal yönü temsil eden insandır. İnsan, insansı bir varlık olan beşer statüsünden çıkıp tam anlamıyla insanlık niteliğini kazandığı ana kadar tabiatın işleyiş seyrine bağlı olan diğer varlıklarla aynı kaderi paylaşmıştır. Bu anlamda insan, biyolojik gelişimin en yüksek noktası, akli düzenin gelişmesinin ise başlangıcı durumundadır:

"İnsan üzerinden öyle bir zaman geçmiştir ki; bu süre içinde anılmaya değer bir şey bile değildi ..."1 ayetinde insanla ilgili olarak anılmaya değer

1 İnsan 76/1-2. 
görülmeyen yön, insanın bu beşeri yönüdür. İnsanın beşer yapısı, onun zoolojik tarafı ve tabita bağlı olan yönüdür. İnsani yönü ise 'zaman dışı'dır. Bu sebeple insan, kendini sürekli tabiatın dışında metafizik bir alanla irtibatlandırmak zorunda hisseder. Bu özelliği, onun yapısına zerkedilen zamandış1lıktan gelmektedir.

İnsan Tanrı'nın sıfatlarını ödünç alıp tam anlamıyla insan olduktan sonra, gerçekleştireceği hedefler Tanrı tarafından önüne konulmaktadır. İnsanın mecazi olarak ifade edilen yasak meyvayı yemesiyle başlayan bu süreçle, insan üzerinden geçen zaman, tek tip işleyen bir süreç olan beşeri süreçten çıkmakta, artık insanın hayatına anlam katan iyi-kötü, güzel-çirkin, vs. bütün değerlerin aktif olmaya başladığ 1 insani niteliğe kavuşmaktadır. Verilen bilgi ile başka bir ifadeyle isimlerin öğretilmesiyle beşer özelliği sona erdirilen ve insan olarak isimlendirilen varlık, kendine ait bir bilince kavuşmuş ve diğer varlıklardan farkını ortaya koymak amacıyla mahrem yerlerini örtmeye başlamıştır. Tanrısına isyan eden ilk insan, artık bu insan olma sürecinden sonra iradesiyle davranmaya başlamakta bunun neticesinde mutlu olabilmekte, isyan edebilmekte, arkasından af için yakarmaktadır. Tarih artık insanın üzerinden geçmemekte, insanla birlikte işlemeğe başlamaktadır. Zaman İslam öncesi Arapların inandığı gibi onların tek varlık ve yokluk sebebi olmaktan çıkıp, insanla paralel giden, insanın yapıp ettikleriyle faziletler tarihi yahut felaketler tarihi şeklinde anlam kazanan bir sürece, anlamlı ve değiştirilebilir bir sürece dönüşmektedir.

Bu sürecin sonunda bir prototip olarak ortaya konulan insan, özgür ve sorumlu bir varlıktır. İnsanı sorumlu bir varlık olarak resmetmemize imkan veren kavramlar 'irade özgürlüğ̈̈', yapacaklarıyla ilgili olarak bir 'kudrete sahip olma' ve 'bilme'dir. Allah Adem'e isimleri öğrettikten sonra, yani onu bilgilendirdikten sonra hemen onu İlahi buyrukla karşı karşıya bırakmakta, yasak meyvadan uzak durmasını talep etmektedir. Yasağı çiğnedikten sonra Adem ve Havva'nın:"Rabbimiz, kendimize zulm ettik. Bizi bağışlamaz ve bize merhamet etmezsen, kaybedenlerden oluruz" ${ }^{2}$ şeklinde niyazda bulunmaları ve pişmanlık duygusu içine girmeleri, insanın kendisini özgür ve sorumlu saymasının en önemli psikolojik belirtisidir. "Doğrusu size Rabbinizden açık belgeler gelmiştir; kim görürse kendi lehine ve kim körlük ederse kendi aleyhinedir"3 ayeti de, insanın hem özgürlüğüne hem özgürlüğünü kullanmadaki başarısızlığına, hem de bağımlılığına işaret eder.

2 Araf $7 / 23$.

3 En'am 6/102. 


\section{b. Fitrat}

Tanrı ile ilişkisinde insanın konumunu tespit etmeye imkan veren anahtar kavramlardan biri fitrattır. "Hakka yönelen bir kimse olarak yüzünü dine çevir. Allah'ın insanları üzerinde yarattığı Allah'in fitratına sımsıkı tutun..."4 ayetinde insanın istidlal ve mantıksal çıkarımına ve gerçekliği keşfetmesine imkan veren ontik yapıya, fitrat olarak işaret edilmektedir. İnsan, fitratın izin verdiği kadarıyla her düzeydeki varlık hakkında bilgi edinebilir. Zira, fıtrat; insanın kendisine göre yaratıldığı prototiptir ve insanın kapasitesini ve sinırlarını göstermektedir.

Fttrat, Allah ile insanlar arasında hem birlikteliğgin hem de farklılı̆̆ın zeminidir. Ayette, 'Allah'ın insanları üzerine yarattığı Allah'ın fitratı' bu birlikteliğe taban sağlarken, terimin kök anlamı, Allah ve insan arasında farklılığ getirmektedir: İ mak anlamlarına gelmektedir. Bu da, Allah'ın kendi mahiyetinden farklı olarak meydana getirdiği ve kendine has kurallarını yapısına yerleştirdiği bir varlık formu demektir. Bu farklı fitratlara sahip olma durumu, hem insan hem de diğer varlık tarzları için geçerlidir.

İnsanın bu fitri/ontik durumunun fonksiyonel olabilmesi ise, ancak bilgisel/epistemik bir insani yapının, zihinsel bir ön hazırlı̆̆ın ve bilincin varlığıyla mümkün olabilmektedir.

\section{Insanın Epistemik Yapısı}

\section{Hidayet}

İnsanın kendi dışındaki varlık alanını keşfedip anlamasına imkan veren epistemik yetenek Kur'an'da hidayet terimi ile kavramsallaştırılmıştır. Hidayet yeteneğinin korelasyon kurup keşfedeceği varlık alanı ise takdirdir. Hidayet ve takdir arasında kurulan ilişkinin niteliği ise Hakk olarak anılmaktadır. ${ }^{5}$ Hidayet genel anlamıla sezginin, duyuların ve aklın rehberliğini, Hakk ise Varlığın ortak niteliğini ve gerçekliği temsil etmektedir. Bu iki kavram birbirini bütünleyen gerçeklikler olarak, bütün insanlarda varolan ve sorumluluklarının da temelini oluşturan kök paradigmaların kavramsallaşmış halleridir. Zira, İlahi irade varlıklara bir hayat tarzı verdiğinde, bunu aktüelleştirebilmeleri için onları doğal gereçlerle donatır:

"Bizim Rabbimiz, her şeye hilkatini (varlık ve özelliğini) veren, sonra da doğru yolu bulacak yeteneklerle donatandır (hidayet)" ${ }^{6}$

\footnotetext{
4 Rum 30/30.

5 Yunus 10/36.

6 Tâ Hâ 20/50.
} 
"Hem, bize yollarımızı göstermiş olduğu (hidayet ettiği) halde, ne diye biz, Allah'a dayanıp güvenmeyelim?". ${ }^{7}$

Hidayet insana, akıl ve duyularının kendisine gösterdiği ve öğrettiğginin ötesinde, varlığını bir bütün olarak sorgulama ve nihai endişelerine cevaplar aramanın kapısını aralar. Şüphesiz, hidayet kavramı salt metafiziksel söylemlere kurban edilecek zihinsel bir kavram değildir. Aksine, hem bireyin kendini değerlendirmesinde hem de toplumla kuracağı ilişkide nasıl bir hukuku ve ilişkiler ağını hakim kılacağını belirleyen şemsiye bir terimdir.

İnsanda tek bir epistemik/bilgisel yetenek olmadığı için, hidayet, insanın bu karmaşık bilme yetenekleri için aşama aşama rehberlik anlamını ifade etmektedir: içgüdüler duyu verileriyle, duyu verileri ise akıl ile kontrol edilmektedir. Hidayet bütün bu süreci kontrol eden bir dış güç, yapıp edilen her şeye bir anlam veren ve iyi ve anlamlı olanı sürekli kılan bir kontrol sürecidir.

Kur'an'ın A'lâ suresinde hidayet'in ardından şu ayetin takip etmesi bu anlamda önemlidir: "Sana aşama aşama öğreteceğiz de unutmayacaksın". Bu durumda hidayet kavramının köken sağladığı bilme, aşamalar kaydederek aydınlanmayı ve tekamülü içinde barındıran bir iç anlama sahiptir.

\section{Insanı Yetkinliğe Hazırlayan Teolojik Paradigma: Bireye Karşı Kişi; Ortodoxi'ye Karşı Ortopraxis}

İnsanın mahiyeti ve dünyada kendisine nasıl bir sorumluluk alanı açıldı ̆̆ı ve bu sorumluluklarını yerine getirebilmesi için ne tür yetilerle donatıldı ̆̆ konusunda çok farklı teorilerin olduğu tartışma götürmez. Bu teoriler üzerinde uzlaşmak ise hiç bir zaman mümkün olmayabilir. Ancak insanın yaşanabilir bir dünya kurmak için yapması gerekenler konusunda fazla bir fikir ayrılığı olmaz. O halde, teolojik olarak, insanlar arasında uzlaşma yaratacak kavramsal retoriği, Kur'anın ifadesiyle, ortak kelimeyi/paydayı ${ }^{9}$ teorilere ve spekülatif doğruluk söylemlerine kurban etmeden pratik bir alan üzerinden kurmak gerekir.

Ayette inananlar arasındaki ortak olduğu peşinen kabul edilen kelime, etimolojik olarak, söz ve kelamın dışında otorite, ağırlık, önemli ilke, vs. anlamlarına gelmektedir. Bu da ortak payda alanının çok geniş bir zeminde aranması gerektiğini, salt sözel/teorik zemin arayışlarının kısır kalacă̆ını

7 İbrâhim 14/12.

8 A'la 87/6 (Ayetin yorumu için ayrıca bkz. Abdullah Yusuf Ali, The Holy Qur'an: Text, Translation and Commentary, Maryland, 1983).

9 Al-i İmran 3/64 ("De ki: Ey Kitap Ehli! Bizimle sizin aranızda ortak bir kelimeye/ilkeye gelin. Yalnız Allah'a ibadet edelim. Ona hiçbir şeyi ortak koşmayalım. Birbirimizi Allah'ın dışında rabler edinmeyelim ..."). 
göstermektedir. Ortak kelimenin üzerine oturacağ 1 geniş zemin, insani endişeler ve insanca bir yaşam için gerekli olanı kurmamıza imkan verecek ve bizi bu yönde motive edecek ilkeler bütünüdür. Bu pratik alanın dini literatürdeki adı 'ahlak'tır. Ahlak'ın köken olarak (h.l.k.) yaratmak anlamına geldiği dikkate alındığında, varolmanın, yaratarak ve eylemde bulunarak varolmak olduğu net bir şekilde görülmüş olur.

$\mathrm{Bu}$ varsayımımıza temel olmak üzere de, teolojide insanı birey (ferd/individual) olarak tanımlamak yerine kişi (şahıs/person) olarak nitelemek daha uygun düşmektedir. Zira birey, tek başına insanı, kişi ise başkaları ile ilişki halindeki insanı tanımlar. Teolojinin nihayetinde ilişkiler ağı içindeki varlıklar (Allah-alem-insan, vs.) üzerine konuşma olduğunu düşündüğümüzde, bireyin temel haklarını baki tutmak kaydıyla, kişinin daha büyük bir vurguya sahip olduğunu görmüş oluruz. Zira, bir kedi ve ağaç da birer ferdiyete (birey) sahiptirler, ama sadece insanın kişi olmak yeti ve yetkinliği vardır.

İnsanı kişi kategorisine yerleştirirken, sadece akleden yahut sadece yapıp eyleyen varlık olarak tanımlamayız. Zira, bir bütün halinde hayatı anlamaya, yorumlamaya ve yaşamaya çalışan insan zihni bir hükme varmadan şu düzeylerden geçerek hem diğer varlıklardan ayrılmakta hem de ferdiyet/ bireysellik düzeyinden kişilik/şahsiyet düzeyine yükselmektedir:

a. Duyu organlarıyla algılamanın gerçekleştiği tecrübi/ampirik düzey

b. Algıladıklarımızı anlamaya ve açıklamaya çalıştığımız zihinsel/entelektüel düzey

c. Önerme haline getirmeye çalıştığımız anlayış ve açıklamalarımızın do $\breve{g}$ ruluk ya da yanlışlı̆̆ını test ettiğimiz akli/rasyonel düzey

d. Rasyonel olduğuna karar verdiğimiz bilginin bize bir sorumluluk yüklediği bilinç ve farkındalıkla fiilde/amelde bulunma düzeyi.

Bu sürecin sonunda bir yaratıcılık ve eylem vardır; bunun için de teolojik düşünme, salt spekülatif bir egzersiz olmanın ötesinde bir edim ve eylemdir. Vahiyle ve vahyin kaynağ 1 ile irtibat düşüncesi, insan zihninin bir hükme varmada takip ettiği bu süreçlerin her birini çok daha aktif, anlamlı ve sürekli kılmaktadır. Bu anlamda dinin ihtiyaç duyduğu varlık salt bir birey değil, kişi olarak öne çıkmaktadır.

Teolojik olarak birey ve kişi arasındaki bu ayırımı yaptıktan ve dinin tarihte yer tutması için kişiye muhtaç olduğunu ortaya koyduktan sonra, kişinin etkin olacağ 1 çerçeveye geçebiliriz.

Tartışmasız, inanan insanlar bir metin geleneğini takip etmektedirler. Bu metin hem bireyleri hem de tarihi kurmaktadır. Öte yandan hem metne hem de tarihe tercüman olma görevi ise insanın omuzlarına yüklenmektedir. Bu görev, insanı sıradan tarihsel bir varlık olmanın ötesine geçirip temel 
özne durumuna yükseltmektedir. Zira teolojik olarak, insan, hem metnin hem de tarihin dilidir. Eylem alanı olduğu kadar bir yorum alanı da olan tarihi yorumlamada insanın kullandığı dil ise, karşıtlıklar ve gizli hiyerarşik ilişkiler üzerine kurulu bir varlık alanına bağlı olarak oluşan dildir. Bu belirlenim içindeki dil, tarihsel olana ilişkin ürettiği ve yorumladığı kavramları, aynı sürecin devamını sağlayacak şekilde kullanma eğilimindedir. Bunu aşmak için insan, dil'in tarihi yorumlarken oluşturduğu kavramların, hem doğru bilgiye (orthodoxi) hem de doğru eyleme (orthopraxis) götüren temel kriterlere (furkan) göre hareket etmesini sağlamalıdır. Teolojinin toplumsal olanı dönüştürücü olan ve bu anlamda toplumsal matrise oturan bu teo-praxis niteliğinin, ayağı yerden kesik felsefi spekülasyonlara önceliği vardır. Bu bağlamda, düşünce alanında geliştirilmeye çalışılan sağlam sanı (ortodoksi), tarih alanında yerini doğru eyleme bıraktığında, tarihi doğru eylem alanı olarak yorumlayacak teolojik bir öz kavramlar dizgesi (iman ve amel) de hayat bulmuş olacak ve tarih, yaşayanların tarihine dönüşecektir. Ayağı yere basan, başka bir ifadeyle tarihin ve doğanın reel yasalarını, teorik kurgularla paralel kılan bu yaklaşımla tarihin aktörleri durumundaki insan, kendini tekrar etme anakronizminden ve daha da kötüsü, tarihi geriye doğru sarma paranoyasından kurtulabilecektir.

Teo-praxisin öncelendiği bir teolojik yorumda, Tanrı zamansız ve zamandışı cevherler kanalıyla iş yapmaz, olayların diliyle konuşur ve kendini müminleri vasttastyla doğrudan tarihi olaylarda gösterir. Zira, dinlerin Tanrı öğretileri pratik ve pragmatik amaçlıdır. Hiçbir din Tanrı'sından ilgisiz bir şekilde, bir etki ve fonksiyona tekabül etmeyecek şekilde bahsetmez. Teolojik dilin amacı, hiçbir şekilde sadece Tanrı hakkında bilgi vermek olamaz. Bu anlamda dinin hitap dili sadece olup biteni anlatan (informative/ descriptive) bir dil değil, anlatımlarının bireysel ve toplumsal matrise oturmasını ve tarihte yer tutmasını isteyen ve bunu inşa eden (performative/ prescriptive) bir dildir. Bu dil mensuplarından Tanrıy sevmelerini, ona ibadet etmelerini, ona güvenmelerini ister ve bu aktların her birinin de karşılık bulduğu pratik bir alanın yaratılmasını öngörür. Teolojik hakikat anlamını ve içeriğini, tek başına bir gerçeklik dünyasını temsil etmenin ötesinde, adalet, hürriyet, barış gibi, anlam içeriklerini tanımla değil uygulamayla kazanan kavramlardan alır. Pratik bir uygulama alanının varlığıla varlık kazanan, yokluğuyla da soluklaşan bu kavramlar, teolojik sistemler için birer turnusol kağıdı işlevi görürler. Dünyanın bu kavramların yapılandırdığ 1 zihin tarafından yorumlanması ve dönüştürülmesi, teolojinin bir süreç yahut tarih içinde yer tutması, sosyalleşmesi kısaca varolmasi demektir. 
Daha önemlisi, teolojik ilke yahut önermelerin doğrulanması, bunların pratik yaşamda açtıkları anlam alanında ve gelecek kurgumuzda bize sağladıkları öngörü ve motivasyonda aranmalıdır. ${ }^{10}$ Önceliğin teolojik önermelerin bu pratik yönüne kaydırılması, bunların bir anlamdan yoksun olduklarını ima etmez, aksine onlara artı bir değer yükler. Ayrıca bütün pratiklerin teori yüklü olduğu başka bir deyişle, pratiği önceleyen zihinsel bir kabullenmenin ve kabullenmeleri temsil eden kavramlar dizgesinin var olduğu unutulmamalıdır. Bu teori ve pratiğin birlikteliği, 'hakikat' kavramının içeriğini oluşturur.

Hakikat olarak algıladığımız şey, dünyayı değiştirecek bir girişime motivasyon sağlayamazsa, mevcut dünyanın mitine dönüşür. ${ }^{11}$ Içinde yaşadıkları şartları dönüştürme iradesine sahip olmayanlar, çok geçmeden bu şartları rasyonelleştirme ve rahatsız olmayacakları bir içeriğe kavuşturma eğilimine girerler. Marx'ın Feuerbach'a reddiyesinde yazdığı gibi: Filozoflar farklı şekillerde dünyayı yorumladılar; ama mesele onu değiştirmektir."12 Gönderilen peygamberlerin temel misyonunun bu değişikliği yaratmak olduğunda hiçbir şüphe yoktur. Kur'an özelinde değerlendirildiğinde, bu değişikliğin dinamosu durumundaki insanları bu sürece hazır hale getirmek için ortaya konan kavramlar, tarihe eşlik eden her dönem mü'mininin besleneceği temel referanslar durumundadır.

Bir spekülasyon alanından daha çok bir eylem alanı olması, tarihin Tanrı'nın, adil, hak, razık gibi aktif sıfatlarıyla ilintili olarak yorumlanmasını gerektirmektedir. Allah'ın bu isimlerine tarih içinde yer açma istek ve gayreti, tarihin hem iyiye kodlanmasını sağlayacak hem de tarihi insanın ve Tanrı'nın ortak tarihi haline getirecektir. Bu durumda, tarihte Allah adına hareket ettiği iddiasını dillendirenlerin, bu iddialarının meşruluğu ve değeri, kendi etnik ve dinsel kökenlerini öne çıkarmadan, Tanrısal olan bu isimlere ve sıfatlara tarihte ne kadar yer açabildiklerine bakılarak değerlendirilecektir.

III. Insan Yetkinliğinin Teolojik Kökleri

1. Yetkinlik Arayışlarının İslam Düşüncesindeki İzdüşümleri:

Insan-ı Kamil, Soyutluk Sultanları, Hayy b. Yakzan ve Fadıl b. Natık

Toplumsal alanı, değişme ve gelişmenin başka bir ifadeyle tekamülün alanı

10 Bkz. Dorothee Sölle, Political Theology, Terc. John Shelley, Pa: Fortress Press, Philadelphia, 1974, s. 76.

11 John B. Cobb, JR., Process Theology as Political Theology, Manchester Univ. Press, Manchester, 1982, s. 57.

12 Marx and Engels, Basic Writings on Politics and Philosophy, ed. L.S. Freuer, Anchor Books, N. York, 1959, s. 245. 
olarak kabul edip, bu değişimi gerçekleştirecek insanı yetiştirme çok eski bir insan ve toplum projesi olarak kendini korumaktadır. İnsan-1 Kâmil ${ }^{13}$ (İbn Sina, İbn Tufeyl, Abdülkadir el-Jilî, İbn Arabî), soyutluk sultanları/ ihvânu 't-tecrîd (Sühreverdi),vb. adlar altında sunulan bu insan; bir taraftan, iradesini kör bir teslimiyetle atıl kılmayan, hayatın işleyiș sürecinde aktif bir şekilde rol alan ve değer üreten, diğer yandan da kendisine hitap eden Tanrı'nın sesiylekendi akıl ve bilincinin içsel sesini birleştirmeye çalışan aktif varlığı temsil etmektedir.

Sühreverdînnin soyutluk sultanları (ihvanu't-tecrid) ismini verdiği insan tipolojisi nasıl bir kimlik taşımaktadır? Bunlar, hem teorik hem de pratik kemale (mükemmel düşünüş, mükemmel eylem) ermiş kişilerdir. Bunlar, nebilere has bazı özellikleri kendilerinde toplayabilmekte olup kendilerine öğreten olmadan öğrenebilirler ve Allah vergisi bir önseziye de sahiptirler. $\mathrm{Bu}$ insanlar, kün makamındadırlar ve varlık yaratma gücündedirler. Bir insan bilebilen varlık statüsünde ise yaratabilen varlık statüsündedir de. Böylece, olağanüstü işleri, maddi dünyaya ait olan etkileri yaratabilmeleri de mümkün olur. Kısacası bunlar tezahürlerin yaratıcılarıdırlar (ashâbu'l-berâyâ); bu da onlardaki ilahi kudretin alamet-i farikasıdır. ${ }^{14}$

İnsanın ontik yapısına yerleştirilen tecrübe ve akletme yeteneklerine dayalı olarak yetkinliğe ulaşabileceğini göstermek üzere İbn Sina ve İbn Tufeyl, Hayy b. Yakzan adlı eserlerini telif etmişlerdir. Bu iki müelliften sonra gelen İbn Nefis de aynı amaçla Er-Risale el Kamiliyye'sini ${ }^{15}$ kaleme almıştır.

$\mathrm{Bu}$ eserlerde, bireyin yetkinliği elde ediş süreci ve bu süreçteki sezgisel/ deruni tecrübesi (İbn Sina) ve dışsal tecrübesi ve aklıyla elde ettiği kazanımlar (İbn Tufeyl) anlatılmaktadır. Bu eserdeki temel vurgu şu noktayadır: kimsenin yerleşik olmadığ doğal akıl yürütmesiyle doğal, felsefi ve teolojik hakikatleri keşfedebilmektedir. İbn Tufeylin vurgusu şu noktayadır: Bir ceylan tarafından ıssız bir adada yetiştirilen bir çocuk gözlem ve mantıksal dedüksiyonlarla temel insan bilgisinin bütün köşetaşlarını keşfetmekte sonunda mistisizmin de-

13 Bkz. İbn Tufeyl, "Hayy The Son of Yaqzan", Terc. George N. Atiyeh, Medieval Political Philosophy: A Sourcebook, ed. R.Lerner \& M.Mehdi, Kanada, 1963, s. 134; Leon Gauthier, Hayy ben Yaqdhan, Roman Philosophique d'ibn Thofail, Texte Arabe et Traduction Française, 2 bs., Beyrut, 1936; Hillel Fradkin, Ibn Tufayl's Hayy ibn Yakzan on the Relationship of Mysticism, Prophecy and Philosophy, Doktora Tezi, Chicago Univ., 1978, George Hourani, "The Principal Subject of Hayy ibn Yaqzan", Journal of Near Eastern Studies, No:15, 1956, s. 40-46.

14 Hüseyin Ziyaî, "Sühreverdî: Aydınlanmacı Felsefe Doktrini (Otoritenin Kaynağına Doğru)", ed. Charles E. Butterworth, İslam Düşüncesinde Siyasi Düşüncenin Gelişimi, İstanbul, 1999, s. 284

15 Bkz. The Theologus Auto-didactus of Ibn Al-Nafis, ed. Max Meyerhof \& Joseph Schacht, Oxford, 1968. 
rinliklerine kadar ulaşmaktadır. Önce ölü hayvanları parçalayarak öğrendiklerinden bitkilerin anatomisine geçmekte, buradan meteorolojik olgulara ulaşmakta, ardından semavi cisimlerle ilgili bilgileri keşfetmekte ve sonunda Yaratıcının varlığı ve sıfatları bilgisine erişmekte, bu sıfatlar üzerindeki refleksiyonu onu Allah'a karşı yükümlülüklerine götürmektedir.

\section{Insani Yetkinliğin Teorik Yapısı}

a. Dinin Tekamüle Ermesi (Vahyin Kesilmesi): Insana Açılan Alan

Kur'an, dinin tekamüle erdirildiğini ifade etmektedir. ${ }^{16}$ Bunun iki anlamı vardır: ilk olarak, yeni bir vahiy indirme dönemi kapanmış ve vahyedilen dinlerdeki ilkelerin hayata geçirilme dönemi başlamıştır. İkinci olarak da, Muhammed İkbal'in vurguladığ şekliyle, artık insan bundan sonra kendi yağıyla kavrulacaktır. Zira, Kur’an vahyi büyük vurgularla, insanın rasyonel ve bilimsel yeteneklerini açığa çıkartmaya ve insanın bunların farkında olmasını sağlamaya çalışmaktadır.

Her iki durumda da, insan bu süreçte kazandığı bütün yeteneklerini aktif kılmak ve kendisine yüklenen ve altından kalkması emredilen sorumlulukların ('ukûd) ${ }^{17}$ altından kalkacak yeteneklerini geliştirmek zorundadır. Bu sorumluluk alanının ('ukûd) genişliği, insanın bunun altından kalkacak yeteneklerle donatılmış olmasını gerektirmektedir. 'Ukûd, bizi dışımızdaki varliklara (organik ya da inorganik, ideal ya da real, maddi ya da manevi) bağlayan her türlü bağ ve sorumluluktur. Bu sorumlulukların başında da, insanın ruhsal yapısından ve Allah'la ilişkisinden kaynaklanan ilahi sorumluluklar gelmektedir. Her bir sorumluluk alanının denk düştüğü ontik yahut epistemik bir insan yeteneği vardır. Epistemik yetenek olarak insanla ilgili olarak Kur'anın lübb, fuad, sadr, kalb, akıl, basiret, vs. vurgusu bu genişliği göstermektedir.

\section{b. Ilahi Metnin Illi/Kozal Yapısı}

Vahyin illi yapısı, başka bir ifadeyle anlatımın sebep-sonuç ilişkisi çerçevesinde cereyan etmesi ve okuyucunun akıl ve tecrübesine hitap etmesi, okuyucu ile metin arasında iletişimi mümkün kılan temel unsurdur. Akıl ve vahiy arasındaki karşılıklı-zorunlu ilişkiyi mümkün kılan bu durum, vahyin dogma olarak adlandırılmasını engeller. Zira dogma, yapısına nüfuz edilemeyen ve tartışılmadan kabul edilen doğruluk iddiaları için kullanılmaktadır. Vahyin, kendisini anlayacak ve yorumlayacak insanlara gelmiş olması

16 Maide 5/3 (Bugün sizin için dini tekamüle erdirdim...)

17 Maide 5/1 (Ey inananlar! Akitlerinizi/sorumluluklarınızı yerine getirin). 
ve aklın süzgecinden geçerek ifadelendirilmiş olması, dogma olarak ifadelendirilmesini imkansızlaştırır. Aynı şekilde, Kur'an'ın ilke ve hükümlerinin belli sebeplere (illetlere) dayandırılmış olması, açıklamalarında sürekli argüman ve delil getiriyor olması, hükümlerin uygulanmasında gösterilen esneklik, zaman ve mekan'ın getirdiği şartlara bağlı olarak üzerlerinde yeniden düşünülmeye açık oluşları (içtihad), vs. dikkate alındığında dogma olarak adlandırılamayacakları ortaya çıkmış olur. Savaş zamanında hırsızlık yapana ceza uygulanmaması, bu örneklerden biridir. Yine Hz. Ömer'in, kalpleri İslama ısındırılmak (ve kötülüklerinden emin olunmak) istenen kişilere zekat verilmesini emreden ayetin hükmünü, İslam toplumunun kendi ayakları üstünde durduğu ve bu tür desteklere ihtiyaç duymadığı yönündeki kanaatinden sonra kaldırması ve ayeti uygulamaması yine bu örneklerdendir. Bunlar da, dinin bünyesinde insana açılan geniş alanı göstermektedir.

\section{c. Metni Yorumlama ve Uygulamada Insanı Etkin Kılan Yorum Aygıtları}

Dilsel çözümlemeyle anlaşılabilecek bir metne dayanması sebebiyle, İslam düşüncesinde 'dil'in ve dile dayalı tahlillerin ayrı bir yeri olduğu tartışmasızdır. Zira, metnin anlamını açığa çıkaracak yöntemi geliştirme, nihayetinde, metnin dışındaki öznenin elindedir. Kur'an ayetlerinin bir kısmını inşai (bir fikir ve hüküm içerenler) bir kısmını ihbari (hüküm içermeyip sadece bilgisel bir içeriği sahip olanlar) şeklinde ayırıp, Kur'an'dan elde edilen verilerin bu kategoriler içinde mütalaa edilmesi; Kur'an yorumunda lafzın mı yoksa anlamın mı daha büyük bir ağırlık taşıması gerektiği yönündeki büyük tartışmalar, öznenin bu süreçteki ağırlığını gösteren örneklerdir. Bu çerçevede, müslüman düşünürler te'vil (hermenötik) geleneği aracılığı ile insanın lafzın ötesine geçip hükümler çıkarmasının yolunu açmışlar ve etkinleştirmişlerdir. Te'vil geleneğinin nasıl ve hangi temel kavramlar üzerinden işletildiğine geçmeden önce, modern düşüncede okuyucunun metin üzerindeki etkinliğinin nasıl öne çıkarıldığını göstermek üzere okuyucu tepki teorisine dikkat çekmekte yarar var.

\section{c1. Okuyucu Tepki Teorisi}

Okuyucu tepki teorisi (Reader Response Theory), ${ }^{18}$ anlamın dinamik olarak algılanmasına zemin hazırlamaktadır. Bu dinamizm yani metnin ve

18 Okuyucu tepki teorisi için bkz. Wolfgang Iser, 'Interaction between text and reader, "The Reader in the Text: Essays on Audience and Interpretation, ed. Susan R. Suleiman and Inge Crosman Princeton University Press, Princeton, NJ, 1980, s. 106-19. Reader-Response Criticism: From Formalism to Post-Structuralism, ed. Suleiman, Crosman ve Jane Tomkins, Johns Hopins University Press, Baltimore, MD, 1980; Elizabeth Freund, The Return of the Reader: 
okuyucunun işbirliği, anlamı ortaya çıarmaktadır. Her ikisinin katkısı olmadan metnin anlamı tam olarak ortaya çıkamaz. Teori, okuyucunun bu dinamik tepkisine ve katılımına vurgu yapmaktadır. Buna göre hiçbir metin bütün hikayeyi anlatmaz, arada sürekli okuyucunun doldurmasını istediği boşluklar bırakır. ${ }^{19}$ Okuyucunun bu boşlukları doldurmasına imkan veren ise onun ontik ve epistemik yetenekleridir.

Okuyucu tepki teorisi, anlamın bütünüyle yazarın zihninde bulunduğu ya da anlamın bütünüyle dışarıda bir eylem yaratmaya yönelik olduğu yönündeki anlam teorilerine karşı geliştirilmiştir. Bilinmektedir ki, postmodernistler, insanın otonom yorumlarına yer açmak için metnin içinde kendine has, yazar tarafından (teoloji bağlamında Tanrı tarafından) yerleştirilmiş bir anlamı bulunmadığını iddia etmektedirler. Okuyucu tepki teorisi, bilginin her zaman bir yorumla bize ulaştığı şeklinde ifadesini bulan Ricoeur'un hermenötik felsefesiyle de yakından ilgilidir.Bu teoride, metinde söylenen kadar söylenmeyen de önemlidir. Okuyucunun yaratıcı faaliyeti durumundaki yorum olmadan metnin anlamı bütünüyle ortaya çıkmaz. Bu durum, Gadamer'in ifadesiyle bir tür 'ufukların birleşmesi'dir. Bu yaklaşım, hem yazardan hem de okuyucudan bağımsız bir 'anlam'ın aşkın olarak var olduğu yönündeki Platonik felsefeye de karşıdır. Metin sadece okunduğunda vardır. Okunduğunda varolan metin de okuyucuyu yapılandırır.

Öte yandan, dini ifadeler, bir yaşam tarzının ve bu yaşam tarzını sembolize eden eylemler bütününün deklare edilmiş halidir. Bu yüzden din dili ve bu dil içinde kullanılan meseller/paraboller nihayetinde bu yaşam tarzını ve eylemleri yaratacak iradeyi oluşturmaya yöneliktir. Kur'an bu yaşam tarzını kuracak eylemlerden bahsederken tek tek eylemleri saymaktan ziyade bunların genel niteliklerinden bahsetmekte, bu suretle niceliği değil niteliği öne çıkarmaktadır. Böylece, takip edenlere takip etmeleri gereken bir eylemler bütünü empoze etmekten ziyade, yapacakları eylemlerin iyilik ve kötülük niteliklerini kendilerinin düşünmelerini istemektedir. Eylemlerin iyilik ve kötülük niteliklerini seçmede kula Allah'ın duyduğu güvenin kaynağı, bu yetiyi onun ontik yapısına başka bir ifadeyle fıtratına yerleştirmiş olmasıdır. Böylece okuyucunun metinle inter-aktif bir diyalog kurmasının da yolu açılmaktadır. Metnin eylemlere bu yönde bir temel oluşturacağı yönündeki yorum ve anlayış, metnin okuyucudan beklentisini de artıracak,

Reader-Response Criticism, New Accents, Methuen, London, 1987; Michael Vander Weele, "Reader-response theories," Contemporary Literary Theory: C Christian Appraisal, William Edrdmans, Frand Rapids, MI, 1991, s. 125-48.

19 Dan Stiver, The Philosophy of Religious Language: sign, symbol and story, Blackwell Publishers Inc., Massachusetts, 1996, s. 108. 
okuyucuya daha büyük bir sorumluluk alanı açacaktır. Bu yönden hem metnin hem de okuyucunun karşılıklı katkısı söz konusudur. Okuyucudan beklenen bu katkı sebebiyle, Kur'an bazen bütün hikayeyi anlatmaz, boşluklar birakır ve bunları okuyucunun doldurmasını arzu eder. Böylece metin ve okuyucu arasında anlamı yaratmak üzere sürekli bir hermenötik daire çizilir:

"Ancak Allah şuurunu canlı tutanlar (takva) için bir hatırlatma olmak üzere... kitabı indirdik" 20 ayeti de okuyucunun metinle ilişkisinin düzeyini tahlil açısından anahtar konumdadır. Ayetteki 'hatırlatma' terimi iki şekilde önümüzü açmaktadır: İlk olarak, Kur'an'ın muhatapları üzerinde bir etki yaratıp yaratmaması onların zihin haline bağlıdır. İkinci olarak da, metnin görünen lafzi yapısının dışında hatırlanması istenen bir anlam alanına sahip olduğudur. Bu literal yapı, bu anlam alanına ulaşmanın referansı, başlangıç noktasıdır. Aslında, metnin lafzi anlamının dışında bir anlamının da varolabileceği ihtimali, algıladığımız evrenin ötesinde bir varlık alanının varolabileceğini kabulle yakından ilişkilidir. Nasıl fiziki dünyanın tekdüze ampirik bir dille ifadelendirilmesi, gözlemciyi dar bir fiziksel ontoloji içine hapsederse, aynı şekilde metnin sadece literal yorumu da yorumcuyu metnin lafzi çerçevesine sıkıştıracaktır. Fiziksel ontolojinin bunaltıcı çerçevesinin dışına çıkmak için matematiksel dilin kullanılması gibi, daraltıcı literal metnin dışına çıkmak için de din dilinde semboller, metaforlar, vs. kullanılmaktadır.

\section{c2. Te'vil/Hermenötik}

Aslına döndürmek anlamındaki e-v-l kökünden türeyen te'vil, bir şeyi görünen, lafzi anlamını yorumlayarak asli formuna kavuşturma ve ilk haline götürme anlamına gelmektedir. Kur'an'da, söylenen sözleri, olayları ve rüyaları yorumlama anlamını ifade edecek şekilde kullanılmaktadır (Yusuf 12/6, 21, 36, 37, 44, 45, 100, 101 ve Kehf 18/78, 82).

Te'vil'in İslam düşüncesinde bir yorum aracı olarak kullanılması, insanın yorumlarında kaçınılmaz olarak başvuru kaynağı olarak tuttuğu metin karşısındaki durumunu ortaya koyması açısından son derece önemlidir ve bir zihniyeti ve tutumu yansitır. Zira bu durumda te'vil, metni yorumlarken tecrübeyi ve aklı (re'y/dirayet) kullanmayı ifade etmektedir. Bu anlamda, İmam Maturidi, tefsiri (lafzın karşılığını vermeyi) sahabeye, te'vili (yorumlamayı) ulema'ya düşen iş olarak görmektedir. Maturidi, te'vili alimlere düşen görev olarak görürken çok temel bir yorum yönteminin de altını çizmektedir: Kur'an ayetlerini yorumlamak, onların ne anlama geldiğini ortaya koymanın ötesinde bir şeydir. Bu tutum, lafza verilen anlamın mutlak 
olduğu gibi bir varsayımı dışlar. Bu da Kur'an yorumunun ucunun açık olduğu, tektipleştirilemeyeceği, tek bir yorumun mutlaklaştırılıp bütün toplumun önüne uyulması gereken bir 'inanç ilkesi gibi' konulamayacağı, gibi sonuçlar doğurur. Verili metinler üzerinden geleneklerini kuran toplumların, bu metinle ilişkilerinin, bütün sorunları metin üzerinden ve metin seviyesine indirerek çözme anlamında aşırı lafızcılı̆̆ın, onların başına ne tür sorunlar çıkardığı düşünüldüğünde bu yöntemin önemi daha iyi kavranacaktır. Aşırı lafızcılığın karşıtı olmak üzere Hanefi-Maturidi çizginin, Malikilerle birlikte, diğer düşünce ekollerinden farklı olarak, insan yorumuna daha fazla yer açan istihsan, istislah, kamu yararı (mesalih-i mürsele) gibi hüküm çıkarım yöntemlerine sarılmasının mantığı da burada yatmaktadır.

Kur'an, insana hitap ederken doğal olarak beşeri bir dil ve terminoloji kullanmaktadır. Kur'an'ın insana ulaşmak için kullandığı bu düzlem, vahiy ile beşeri dili aynı ufukta birleştirmektedir. Kur'an'ın ilahi hitabın içeriği ile ilgili olarak insanı tefekküre teşvik etmesi ise, öncelikle vahiy dilinin anlam yapıs1na ulaşmayı gerektirmektedir. İnsanın, vahyin taşıdığı anlamı temsil eden lafızlar üzerinden bu anlama ulaşacak fitri ve bilgisel yeteneklerle donatılmış olması, bu anlama ulaşmayı mümkün kılmaktadır. Dolayısıyla insan, yapısı gereği hem tabii varlık alanını, hem de bu varlık alanının metne dökülmüş anlatımını kendi haline bırakmayıp te'vil eden, yorumlayan bir varlıktır. İnsanın yorum etkinliğinin aracı olan dil de, insanın kendisini de içine alan bu varlık alanının mükemmel seviyede gramerini göstermekten başka bir şey değildir. Bu yorumlama, aynı zamanda, insanın bütün varlığıyla içine katıldı$\breve{g}_{1}$ bir sorgulama sürecidir. Kendine anlam ve eylem alanı açan gerçek bilgi de, ancak bu te'vil sürecinin sonunda ortaya çıkmaktadır.

Tartışmasız te'vile konu olan vahiy, insanlar arasındakinden farklı bir iletişim zemininde gerçekleşmektedir. İlahi kelam, aşkın bir yapısı olsa da, insanın kullandığı lafızlara bürünerek nasta vücut bulmaktadır. Vahyin iki kapak arasına gelmiş hali durumundaki Kur'anın anlaşılmasında normalde başvurulmayan çözümleme yöntemlerine başvurulması, bu farklılıktan kaynaklanmaktadır. Kur'anın dilsel olarak mecaz, istiare, vs. anlatım yöntemlerini kullanmış olması, yorumcunun karşısına çoğu zaman çelişik gibi görünen, dolayısıyla yoruma muhtaç çok geniş bir anlam alanı çıkarmaktadır. $\mathrm{Bu}$ anlam alanının anlaşılmasını sağlamak için belagatçiler 'mecaz', İslam kelamcıları ise 'te'vil' kavramını geliştirmişlerdir. Te'vil bir şeyin evveline ulaşmak olduğu için, metnin arkasında yatan gerçek anlamı keşfetmek için zihinsel bir çaba gerekmektedir. Bu çaba, olayları sadece olgusal düzeyde değerlendirme riskini ortadan kaldırır ve metnin ve eşyanın görünen yüzünün ötesine geçme imkanı sağlar. 
Metnin her zaman okuyucusunu dönüştüren bir yapısı vardır. Bu dönüştürme, okuyucunun metne ve metnin akış sürecine eşlik etmesinden kaynaklanır. Metnin akış sürecine okuyucuyu katan ise, onun yorumlayan/te'vil eden biri olarak metnin karşısındaki durumudur. Bu durumda metin insanlar üzerinde sadece yaptırım gücü olan bir şey değil, aynı zamanda anlam kaynağı ve delalet merciidir. Te'ville, te'vil eden kişi naslarda daha önce keşfedilmeyenin, ortaya çıkarılmayanın ardına düşer, meçhulden ma'lumu çıkarır, anlamsız gibi duran lafızlara hayat verir. İnsanın bilmediğini öğrenmesi yahut eşyayı yeniden yorumlama anlamında tanımlanan ilim tam da te'vil yoluyla gerçekleşir. Zira yeniden yorumlanmak suretiyle asli nitelikte olan şeyler sürekli yeniden keşfedilir. Bu metinlerin yeniden keşfi, aynı zamanda, onları yorumlayanın kendisini de yeniden keşfetmesi demektir. Bu anlamda Te'vil, insanı aktif bir yorumlayan olarak tasarlamaktadır. Bu yaklaşımda insan dıştan gelen uyarıya pasif bir tepki veren insandan, aktif ve açık bir sistem olarak algılanan insana çevrilmektedir. Bu aktif insan aynı zamanda bulunduğu ilişkiler ağı içinde sürekli değişmekte ve gelişmektedir. Bu durumda yorumun kaynağı statik insan yetileri değil, insanı besleyen her türlü veriye kaynaklık eden daha geniş tabanlı bir bilgi, kültür, ve tecrübe düzlemidir. Bu geniş düzlem, yorumu sadece tekil insan ürünü bir çıkarım olarak görüp, öznel olarak nitelemeyi engeller.

Özne, yorum ve hüküm çıkarımında, geniş tabanlı bir bilgi, kültür, tecrübe, vs. alanını dikkate almakta ve te'vilini bu çerçevede yapmaktadır. Öznenin metin üzerinden kendi düşünce ve tecrübesini de anlamlı kılmasına imkan verecek şekilde, İslam düşünürleri bazı temel terimler geliştirmişler ve öznenin yorumunu bu çerçevede meşru bir zemine oturtmuşlardır. Örneğin, içtihat konusundaki tartışmalar, dini anlama ve yorumlamada, tarihsel ve toplumsal tecrübenin, bu tecrübenin beslediği insan zihninin, kısacası aklın, dinin asli metniyle nasıl bir ilişkisi olacağı meselesi etrafında dönmektedir. İçtihadın, nassların yorumunda akıl kadar toplumsal gerçekliklere, değişime ve buna ayak uydurması gereken bir yaklaşım esnekliğini öne çıkarması bu özne vurgusundan dolayıdır. Zira, bir hükme veya görüşe ulaşmada insan zihnini besleyenler, hem metin hem akıl hem de sürekli değişen tarihsel şartlardır. Bu sebeple, içtihada konu olan olaylar çok hareketli ve çok boyutlu olduğundan, bir müçtehide fetva sorulduğunda, ona cevap verdikten sonra tekrar aynı mesele ile karşılaşması halinde olayı gözden geçirip yeniden içtihatta bulunması gerekir, zira olayın farklı bir boyut kazanmış olması çok büyük bir ihtimaldir. ${ }^{21}$

21 Amidî, el-İhkâm fî usûli'l-ahkâm, Tahk. İbrahim el-Acuz, Daru'l kütübi'l-ilmiyye, Tarihsiz, Beyrut, IV, 454-55. 
- Bilgi üretmede ve yeni bir hükme ulaşmada insana vurgu, Kur'an'da 'istinbat' kelimesi üzerinden yapılmaktadır. ${ }^{22}$ Her türlü makul delillendirmeyi kullanarak yeni bir bilgiye ulaşmak için zihnin işletilmesi anlamındaki istinbat vurgusuyla, işinin ehli uzman (ulu'l-emr) insanlara hem yetki hem de sorumluluk yüklenmektedir. İstinbatla ilgili genel kanı, bunun bir içtihadi faaliyet olduğu ve kıyas, istihsan (gizli kıyas), istislah, istishab (bir şeyi olduğu hal üzere bırakmak) gibi terimler için şemsiye kavram görevi gördüğü yönündedir.

- Dini anlama ve yorumlamada öznenin etkinliğini göstermek için, dikkat çekilmesi gereken bir diğer kavram ise 'istihsan'dır. 'Kıyasa ve benzer uygulamalara bakmadan, bir olayın özelliğini dikkate alarak uygun çözüm bulma yöntemi' olarak tanımlanan istihsan ile karşılaşılan olaylara göre farklılaşan çözüm üretme esnekliği sağlanmaktadır. Bir içtihat faaliyeti olarak istihsan, genel kuraldan ve izlenen yoldan vazgeçip, hukukun amacına daha uygun bulunan başka bir hüküm vermektir. İstihsan yöntemi meşruiyetini Kur'an'ın, hayatın doğal akışına, sosyal gerçekliğe ve insan unsuruna verdiği ağırlıktan almaktadır. Bu yöntem içinde hukukun kuralcı ve şekli yaklaşı$\mathrm{m}$ en aza indirilmekte ve hayatın çeşitli yönlerini ve değişkenliğini yansıtan bir iç dinamizmin varlığı hep göz önünde tutulmaktadır. Zaman ve zemin şartları, üretilecek hükümlerin niteliğini belirleyen unsurlar arasına girmektedir. Hz. Ömer'in genel nitelik taşıyan nasları belli bir olaya uygularken böyle bir uygulamanın dinin genel amaçlarına, hak ve adalet fikrine uygun düşüp düşmediğini göz önünde bulundurduğunu ve duruma göre genel kuralı uygulamayıp, o olaya mahsus farklı bir uygulamaya gittiğinin örnekleri çoktur. Müellefe-i kulubun zekat payının kaldırılması, kıtlı zamanı hırsızlara ceza uygulamaması, iktisadi şartlardaki değişim sonucu diyet miktarlarında yeni düzenlemeye gidilmesi, bu uygulamanın örneklerindendir.

- Öznenin yorum etkinliğinde benzer bir esneklik, 'istislah' terimi ile sağlanmaktadır. İstislah, nassların kapsamına girmeyen ya da kıyas yoluyla nasta düzenlenmiş bir olaya bağlanamayan bir meseleninin hükmünü belirleme yöntemidir ve kıyasla daraltılan hükme ulaşma alanını genişletme çabasıdır. Bu yönüyle de istislâh, katı kıyas modeline karşı geliştirilen bir yöntemdir. Sınırlı nassların hayatın bütün yönlerini ayrıntısıyla kuşatmadığı, esasen dini metinlerin böyle bir iddia içermediği göz önüne alınırsa mevcut boşlukların istislah gibi ictihadi yöntemlerle doldurulması meşru bir zemine oturtulmuş olur. Daha Hz. Peygamber hayatta iken, sahabilerin karşılaştı̆̆ı

22 Nisa $4 / 83$. 
olayları kendisine götürmesi ve bu olayların vahyin nüzulünün sebebi olarak belirlenmesi ve bu olayların ayetlerde anlatılıyor olmas1, istislah ilkesinin doktrinal bazda değil ama uygulamada çok erken bir dönemde başladığını göstermektedir. Sosyal gelişmelere paralel olarak gerçekleştirilen idari, adli ve mali yapılanmada bu prensibin büyük rol oynadığı görülmektedir. Hz. Peygamberden sonra halife seçimi, zekat vermek istemeyenlerle savaş bu ilke çerçevesinde değerlendirilmelidir.

Kişinin yorum etkinliğinde kıyasa (analoji) yüklenen işlev de önemlidir. $\mathrm{Bu}$ işlev irdelendiğinde, kıyasa hem öznenin yorum alanını genişletme hem de daraltma şeklinde iki zıt fonksiyon yüklendiği görülecektir.

'Hakkında açık hüküm bulunmayan bir meselenin hükmünü, aralarındaki ortak benzerliğe (illet) dayanarak hükmü açıkça belirtilen meseleye göre belirlemek' olarak tanımlanan kıyas, bir içtihadi faaliyet olduğu için re'y olarak da adlandırılmaktadır. Re'y isminin verilmesi, naslarda bulunmayan hükümleri çıkarmada, yorumlayan insana yer açmış olmasındandır. İnsan bu yorum etkinliğini 'illet' kavramı üzerinden yapmaktadır. İster delalet isterse kıyas olsun, bir hükmün iki ayrı olay için kullanılabilmesini sağlayan unsurun 'illet' olması önemlidir. Bu illetlerin ortaklığına hükmeden insandır. Bu da hükmün kaynağını bütünüyle olmasa da kısmen insana bağlamak anlamına gelir. Bu durumu dikkate alıp, kıyası sırf re'y ve akla dayalı bir çıkarım yöntemi olarak görenler olmakla birlikte, böyle bir akıl yürütmenin nassı dikkate alarak yapıldığı düşünüldüğünde bunun nakle bağımlı bir delillendirme olduğu görülecektir. 'Kıyas hükmü ispat etmez, izhar eder' şeklindeki usülcülerin söz kalıbı, hükmü koyanın Allah olduğunu, kıyas yapana sadece bu hükmü açığa çıkarmanın kaldığını ima etmektedirler. Bundan, kıyasın bir hüküm yahut delil değil, bir delillendirme yöntemi olduğu anlaşılmaktadır. Bu durumda kıyasın şer’i delillerin dördüncüsü olarak sayılmas1 mecazen böyledir; doğrusu bunun bir dellilendirme yöntemi olduğudur. Bu sebeple Gazali kıyasa deliller arasında değil, delillerin anlaşılmasına yönelik istinbat metotları arasında yer vermiştir. Hanefi usulcüler de aynı görüştedirler. Kıyasa bu özelliğinden dolayı kelamcı usulcüler bir delil olarak değil, delillendirmeye imkan veren bir 'emare' olarak bakmışlardır. Bu durumda kıyasın epistemolojik değeri zanni olur. Bu da kıyasla ulaşılan sonucun, kesin dini bir hüküm olarak iddia edilemeyeceği sonucunu doğurur. Bu husus ironik bir şekilde kıyası savunanların da delilidir. Zira kıyasa gidenlerin yeni bir dini hüküm üretme peşinde olduklarını, oysa Allah'tan başka kimsenin böyle bir yetkisinin olamayacağını söyleyenlere karşı, kıyas taraftarları ortaya koyduklarının zan ifade ettiğini, halbuki Allah'ın gönderdiğinin ise zan değil, kesinlik taşıdığını söylemektedirler. 


\section{Yetkinliğe Köken Sağlayan Temel Kur'ani Kavramlar}

\section{Kitap ve Hikmet}

"Ey Rabbimiz! Onlara, içlerinden senin ayetlerini kendilerine okuyacak, onlara kitap ve hikmeti öğretecek, onları temizleyecek bir peygamber gönder. Çünkü üstün gelen, her şeyi yerli yerince yapan yalnız sensin". ${ }^{23}$

Kitap, insanları belli bir aşamaya getirmekte ve onları ardından hikmet'e teslim etmektedir. Bu anlamda hikmet, insanın kendi yağıyla kavrulmasını, insani yetilerin ve faziletlerin kaynaklık ettiği bir yönelimi temsil etmektedir. İslam düşünürlerinin, İslam bilimlerinin oluşum ve tedvin döneminde yabancı düşünce ve bilimleri 'hikmet' kavramı altında İslam düşüncesinin bünyesine entegre ettiklerini düşündüğümüzde, hikmet kavramının bütün insan etkinliklerini belli normlar içinde içselleştirmenin yolunu açtığını da görmek mümkündür. Zira, çoğu zaman, içinde yaşadığımız ve bizi çevreleyen ve sinırlayan toplumsal düşünme ve hareket etme biçiminin ötesine geçmek için bir üst doktrine ihtiyaç duyulur. Kendi dinamikleriyle evrilemeyen bir toplumu böyle bir doktrin uyandırabilir ve evirebilir. Toplumun görme ve hareket etme kabiliyetindeki bu toplumsal felç ve tutulma (katalepsi) durumunu aşmak için, gönderilen peygamberlerin bu insanları 'kalkın, uyanın' nidalarıyla uyandırmaya çalışmasının mantığı burada yatmaktadır. Alışageldikleri toplumsal matrisin belirleyici değerlerinin dişına çıkmak istemeyen bu gelenek ve ata dini tapıcılarını Kur'an ölüler ve sağırlar olarak deşifre etmektedir:

"Bil ki sen ölülere işittiremezsin, arkalarını dönüp giderlerken sağırlara da çağrıyı duyuramazsın." ${ }^{24}$

\section{Furkan ve Ilham: Kitap ve Hikmetle Geliştirilen Kriterler}

Furkan ve İlham, Kur'an'ın insanın yetkinleştirdiği iki temel kavramdır ve birbirini bütünleyen anlam içeriğine sahiptir. İlham, iyi ve kötüyü bilerek, bu ikisi arasında ayırım yapma gücünü; furkan ise, iyi ve kötünün standardını koyma gücünü (furkan=standart) ifade etmektedir. İlk olarak, iyi ve kötünün ne olduğuna dair bir bilgi insanın ontik/fıtri yapısına yerleştirilmiştir (İlham). ${ }^{25}$ İkinci olarak, bu ontik yapılandırma ile yetinilmemiş, iyi ve kötü amelin getirdikleri ve götürdükleri yani sonuçları vahiy diline 
dökülerek dramatize edilmiş ve modellenmiştir. Bu ontik yapı ve bu yapının Kur'anda deşifre edilmesi, iyi ve kötünün ne olduğuna dair insani standartları (furkan) geliştirmenin yolunu açmış ve bunların uygulama sorumluluğunu ('ukûd) insanın omuzlarına yüklemiştir. Kur'anın insana bu yöndeki rehberliği de furkan terimi altında kavramsallaştırılmıştır.

Böylece değerlere kaynaklık eden çifte bir yapı ile karşılaşırız. Allah, insanın ontik yapısına iyi ve kötüye ilişkin sezgisel bilgiyi yerleştirmekte, ardından bu ontik durumu epistemik bir zemine taşıarak insanın bilgisine konu yapmakta, başka bir ifadeyle iyi ve kötünün örneklerini aktarmakta ve bu yönde tarihin sicilini ortaya koymaktadır. İnsan da kendisine devredilen bu dinsel ve tarihsel mirasla yetkinleştirilmiş bir şekilde önünü aydınlatarak yeni durumların değer koyucusu olarak yetkili kılınmaktadır. Bu yeti ve yetkiyle insanın belli bir seviyeye ulaştı̆̆ 1 varsayıldığ için kendi başına bırakılmaktadır. Ancak bu bırakılış mutlak bir terkediliş asla değildir. Zira, değerlerin ortak kaynağı durumundaki Allah bilinci (takva) bu değerlerin aktiflik kazanmasının yegane sebebidir:

\footnotetext{
"Ĕğer Allah şuurunuzu aktif tutarsanız (takvalı olursanız), o size iyiyi kötüden ayırt edecek bir anlayış verir...". ${ }^{26}$
}

Tanrı'nın dışarıda tutulmasının ve hükümranlığın tek başına insana devrinin nelere malolduğunu, insan insanın kurdudur yahut insan insanın tanrısıdır diyen, zihniyetlerin yarattığı sicilde görmek mümkündür.

\section{Alem ü'l-Emr ve Alem ü'l-Halk: Tarihin Etkin Aktörleri Olarak Allah ve Insan}

Kur'an evrenin iki cephesine işaret etmektedir: Alem ü'l-Emr ve Alem ü'lHalk. Emir alemi, ezeli değerlerin, Ümm al-Kitab'ın bulunduğu alemdir (Filozofların idealar alemi, yahut mutasavvıfların âyân-ı sabitesi). Değişimin hakim olduğu alemde tekamüle doğru bir değişim olduğunda, bu değişime kaynaklık eden değerler özlerini ve ezeli mahiyetlerini yitirmezler. Değerlerin bu sürgit işleyişi şöyle ifadelendiriliyor:

$$
\text { "Biz bir ayet(değer)in işlerliğini kestiğimizde ya da unutturduğumuz- }
$$

Bir taraftan bu ezeli değerlerin değişmezliği, diğer taraftan tekamüle doğru bir gidişin varlığı, birlikte hakikatin başka bir ifadeyle gerçekliğin mahiyetini oluştururlar. Hakikatin emr yönünü Allah'tan alan ve bu husus- 
ta O'nu taklit eden insan, yaratma başka bir ifadeyle bu değerlerin pratize edilip Hayat-ı Tayyibe'nin ${ }^{28}$ gerçekleşmesinde Allah'la ortak hareket etmektedirler. Bilen bir varlık olarak insan değer koyucudur da. Zira, Niebuhr'un ifadesiyle, bilme değer koymayı gerektirir. Varlık ve değer birbirinden ayrılamaz iki kategoridir. ${ }^{29}$

Allah, Kur'an'da ifadesini bulduğu şekliyle, bütün yarattıklarını, "onlara ne isim verip, nasıl çağıracağını görmek için" insana takdim etmektedir. İnsan da onların hepsini isimlendirmektedir -hayvanlar, kuşlar, vahşiler, vs.Bir varlığı isimlendirme, o varlığa sadece bir nitelik atfetmek anlamına gelmez. Bir şeye anlam ve önemini kazandırmayı ifade eder. Gerhard von Rad'ın işaret ettiği gibi, ${ }^{30}$ insanın hayvanları isimlendirmesi, onları kendi hayatına katması, hayatının ayrılmaz parçaları halinde anlamlandırması demektir.

Zira dil, daha geniş ve derin bir anlamda "dış"a yöneliktir. Her dil ifadesi, realiteden bir parçayı, dış dünyadan bir olguyu kasdetmek kudretine sahiptir ve bununla görevlidir... Realiteye müdahale etme arzusu, cümleye anlamını verir. Bir nesneye hükmetme arzusu, o nesneye ismini verir. ${ }^{31}$

Alemi, olması muhtemel evrenler içinde en mükemmeli haline getirme, insanın omuzlarına yüklenen bir sorumluluktur. Dünyanın mükemmel olarak yaratılmaması, oluşumunu hala devam ettiriyor olması ve kendisine dünya isminin layık görülmesi (cennet değil) onun olgunlaşmadığını, ama insan eliyle olgunlaşma potansiyelini içinde barındırdığını göstermektedir. Kutsal Kitaplarda halife (İslami literatür) veya Tanrı'nın çocukları (Hristiyani literatür*) olmaya hak kazanma ancak bu olgunlaşma sürecine katkı koyma ve bunu gerçekleştirme şartına bağlanmıştır.

Vahiy dilinin, hem kategorik imperatif (emir ve yasa mahiyetinde) hem de bir oluşun tasviri olması başka bir ifadeyle ampirik delillendirmelere başvurması sebebiyle, Allah ve insan, varlığın işleyişini sağlayan iki değer kaynağı olarak kabul edilmelidir. İnsan, Tanrı'dan pay alması (Tanrı'nın ona ruhundan üflemesi), kurgulama yeteneği, algı güçleri, aklının yapıcı bilgisi ve apriori (dedüktif) olarak bilme ve tecrübeye dayalı (indüktif) olarak bilgi elde etme gibi yollarla varlığa iştirak ettiği için varlığın temel yapıcı unsuru olarak kabul edilmelidir.

28 Nahl 16/97.

29 Detay için bkz. R. Niebuhr, Radical Monotheism and Western Culture, Harper \& Row, New York, 1960.

30 Gerhard von Rad, Genesis, a Commentary, Westminster Press, Philedelphia, 1961, s. 80.

31 Walter Porzig, Dil Denen Mucize, Çev. Prof. Dr. Vülkü, Kültür ve Turizm Bak. Yay. Ankara, s. 237.

* Tanrı'nın çocukları tabiri Tevrat'ta da Tanrı'nın oğulları olarak geçmektedir. Fakat bu kullanım Kur'an tarafından reddedilmekte (Maide 5/18) ve yerine Tanrı'nın kulları ifadesi yerleştirilmektedir. 
Tarih bir objektifleşme, gerçeklikle yüzleşme alanıdır; zira, insan tarihte sadece yaşamayan, yaşadıklarını, tecrübelerini toplayan, insanileştiren bir özelliğe sahiptir. Bu tecrübeler toplamı içinde yaşadığı ortamın ve yaşam şartlarının şüphesiz belirleyiciliği var. Bu yaşam tecrübesi, insanın beklentilerinin sınırlarını belirleyen bir özelliğe sahiptir; başka bir ifadeyle insan ne olabileceğini, nerelere kadar uzanabileceğini bu yaşam şartları ve tecrübesi içinde keşfedebilmektedir. İnsan olmanın sınırlarını ona öğreten, bir doktrinin ötesinde bu yaşamıdır. Bu anlamda insan ve toplum, statik ilişkiler ağının oluşturduğu monolitik/tekdüze ve sabit bir varlık değildir; aksine, bir gelişme seyriyle oluşan, kendisiyle birlikte kendisini tanımlayan kavramları da değişikliğe uğratan bir yapıya sahiptir. Bunun için de insan ve toplum kavramları, teolojik verileri yorumlamada göz ardı edilemeyecek bir hermenötik arka plan sağlayarak, bizi aşırı idealizmden de kurtarır. Bu sebeple, teolojinin toplumsal olanla ilgili ifadeleri bu süreci ve gelişimi dikkate alarak ve bu süreçle ilişkilendirilerek yorumlanmalıdır. Sürekli aşkın bir boyut dikkate alınarak yorumlanan teolojinin içkinleştiği an burasıdır. Bu içkinlik, kendi kriterlerini üreten bağımsız bir alanın, tarihin varlığına bağlı olarak gerçekleşir. Teolojinin bağlamsal (contextual) olması yani belli bir soysal ve kültürel yapıyla bağlantılı gelişmesi, tarih içinde yer tutmanın getirdiği kaçınılmaz bir durumdur.

\section{Hidayet ve 'Akd: Insanın Iç Gelişim Kanunları ve Zihinsel Tekamülü}

Hidayet insana verilen epistemik yetenek olmanın yanında, türlerin kendi iç gelişim kanunlarını ifade etmektedir: ${ }^{32}$ "Allah her şeye takdirini ve hidayetini verendir"33 Ayeti böyle bir çıkarımın zemini durumundadır.

Allah kanunlar koymuş (takdir), bu kanunları keşfedecek ve böylece hem kendimizi geliştirecek hem de Allah'ın bütün yaratma planında öngördüğü gelişme ve tekamüle ayak uyduracak epistemik yetenek olan hidayeti de fitratımıza yerleştirmiştir. Herkese ihtiyacı olan şeyi ölçüp vermiş (takdir etmiş) ve bu ölçüye uyum göstermek suretiyle tekamül edebilecek içgüdüler ve fiziksel kabiliyetlerle donatmıştır. Takdir tek başına mekanik bir rehberlik olarak insana verilebilirdi; ancak Allah böyle dilememiş ve ardından hidayeti de verdiğini söyleyerek, takdirle yürüyen tabiattan ve içgüdüleriyle varlıklarını devam ettiren hayvanlardan farklı olarak, insan aklının ve iradesinin işlediği bir düzenin kurulmasını irade etmiştir. Düşük seviyedeki can-

32 Allahbukhsh Brohi, "The Qur'an and Its Impact on Human History", Islam: Its Meaning and Message, ed., K.Ahmad \& S.Azzam, Londra, 1975, s. 84.

33 A'lâ 87/3. 
lılara içgüdüler ve duyular verilmiş, böylece hayatlarını devam ettirmeleri sağlanmıştır. Görme, işitme, koklama, dokunma yoluyla kendilerini çevrelerine adapte etmekte ve böylece hayatta kalıp türlerini de devam ettirebilmektedirler. Bütün bu duyusal yeteneklere ek olarak insana hidayet altında topladığımız bir yetenekler bütünü verilmiştir. Bu yeteneği ile içinde sadece duyulara dayanan ve hayvanlarla ortaklaşa paylaştığı içgüdülerini kontrol edebilmekte ve sadece çevresine uymamakta, çevresini değiş̧irebilmekte ve yenilik yaratabilmektedir.

Epistemik/bilgisel bir insani yetenek olarak hidayeti irdelerken, bu bilmenin aşama aşama öğrenmeyi ve gittikçe aydınlanmayı/tekamülü içerdiğini ifade etmiştik. Bu aşama aşama öğrenerek tekamül etme ve aydınlanma hem teker teker her bir birey için geçerlidir hem de bütün bir insanlık için. İnsanın karanlıktan ışığa doğru yürüdükçe aydınlığa çıkması gibi, insanlık da üzerinden çağlar geçtikçe zihnen daha da aydınlığa çıkmaktadır. Bu aydınlığa çıkışa paralel olarak hem insanlığın zihni hem de Kutsal Kitapların dilleri tekamül etmektedir. Yine buna koşut olarak, üzerinden asırlar geçtikçe bilinmeyenler yavaş yavaş gizlerinden sıyrılmaktadır. İnsanın aşama aşama kaydettiği bu bilgi ve gizlerin deşifre edilmesi tecrübesini artırmakta, bu tecrübeyi malzeme olarak kullanan insan aklı (bilgisi) da tekamülüne devam etmektedir. Öte yandan, insan bu yolculuğunda yalnız bırakılmamakta, doğru yoldaki yürüyüşünü sürdürebilmesi için, sürekli bu hidayet yedeğine verilmektedir (Fatiha suresi 6. ayet).

İnsanın bu zihinsel gelişimini ve aydınlanmasını kendisine yapılan hitabın yazılı belgeleri durumundaki Kutsal Kitaplardan takip etmek mümkündür. Böyle bir gelişimi 'adalet' kavramı üzerinden yaptığımızda, şöyle bir gelişim sürecinin izini sürmek mümkün olacaktır:

Teolojik ve moral olarak insanın ilk tabiatını (aşamasını) İbrahim'in ilahi rehberlikle aydınlanmadan yahut normatif bir kaynakla tanışmadan önceki durumu olarak yorumlamak mümkündür. Bu hareket noktası, Adem'de kendini gösteren ve sembolik ve metaforik dilin kullanımını gerektiren çerçeveden daha geniş bir uzlaşma alanı açacaktır. Bu anlamda Kutsal Kitapların dilinin insanın zihinsel yapısına koşut olarak nasıl bir tekamüle uğradığını görmek için, insanın ilk durumunun ciddi anlamda dikkate alınması gerekir; zira normatifliği yahut kuralların nasıl olacağını belirleyen ve şekillendiren insanın bu ilk durumu ve yapısıdır. Bu yapının normatif kurallara kurban edilmesi söz konusu olamaz, aksi halde böyle bir yoruma ne teolojik ne de antropolojik bir taban sağlanabilir. Asıl olan insanın bu ilk halidir; sonradan insana verilen rehberlik ikincil bir durumu gösterir ve birincil durumdaki sapmanın düzeltilmesi amacına yöneliktir; onun yerini almaya ve 
ona yeni bir tabiat vermeye değil. Bu yönleriyle de bu kuralların, Kur'an'ın diliyle şir'a'nın ve uygulama tarzı durumundaki minhac'ın ${ }^{34}$ insan ve toplum yapılarına göre değişiklik göstermeleri temel özellikleridir. Dahası, asıl olan bu kuralları ve normatif yapıyı gerektirmeyen bir durumun yaratılmasıdır, ama tarihsel tecrübe, böyle bir arzunun ancak bir teori ve ütopya olabileceğini göstermiştir. Ama yine de ancak normatif kuralların ışı̆̆ıyla önünü gören ve aydınlanan, hayatını korku temelinde inşa eden insan tipi, ilahi olanın nihai hedef olarak koyduğu insan tipi değildir. Gittikçe özgürleşen tabiat ve insanın (bu özgürleşme süreci onların tabiatına yerleştirilmiştir), hayatın karmaşıklaşmasıyla birlikte özgürlügünün daha da kısıtlandığının ve cendereye alındığının gözlenmesi, ilahi olanın hedeflediği ile insanın geldiği noktada kendine layık gördüğü arasındaki ironiyi ortaya koyması açısından çarpıcıdır.

Ancak tarihin teolojik olarak bu şekilde aşamalara ayrılabileceğini söylememiz, tarihsel safhalarda karşılıklarını bulacak şekilde bir zihinsel farklılıklara şahit olmadığımız anlamına gelmez. Antropologların ilkel insan olarak adlandırdığı (bunun ilkel malzemelere sahip olan ve aralarındaki ilişkileri daha basit düzenlemelerle sağlayan, vs. insan şeklinde adlandırılması daha uygundur) insan ile şu anda yaşayan insan arasında zihinsel açıdan, eşyayı algılama ve sınıflandırma açısından ve kompleks realiteyi daha kolay ulaşılabilir hale getirme yani formülasyonlara gitme ve diyagramlar geliştirme noktasında hem benzerlikler hem de farklılıklar vardır. İnsanlığın gelişmesi, kullandığı kavramların çokluğu ve somuttan soyuta doğru evrilmesiyle ilgili bir husustur. İlkel zihin ile gelişmiş zihin arsındaki en belirleyici fark budur. İlerleme mantığı açısından insan tarihinin başını tutan insanla, sonunda yaşayan insan arasındaki fark, hem insan ilişkilerini kuran ve tanımlayan kavramların varolup olmadığı hem de bu kavramlara yükledikleri anlamda yatmaktadır. İnsan ilişkilerinin sade olduğu bir dönemde, şu an yaşayan insanın, karmaşık ilişkilerini anlatmak için kullandığı terim ve kavramlara yer yoktu. Ama daha önemlisi bazı soyut kavramlara yüklenen anlam değişiklik gösterebilmektedir. Örneğin, insandan bağımsız olarak bir 'adalet' kavramının varolması, bu kavramın içeriğinin 10.000 yıl önce doldurulmasıyla, günümüzde buna yüklenen anlamın aynı olduğu anlamına gelmez. Aşă̆ıda da gösterileceği gibi, adalet'in size yapılana aynıyla karşılık verme olarak alındığı kriminal adalet'ten, size yapılan kötülüğü bağışlamanızın adaletin en üst formu olarak tanımlandığı bir etik adalet anlayışına doğru evrilme söz konusudur.

34 Bkz. Mâide 50/48. 
Teoloji, evrenin tözsel niteliğine değil de, içindeki olaylara başka bir ifadeyle geçirdiği sürece atıfta bulunan, Allah'ın alemle ilişkisini de ezeli ya da hadis bir alem tartışması çerçevesinde değil de, işleyen bir alemdeki olaylarla ilişkisiyle kurarak açıklamaya çalışan bir gelişimi ve ilerlemeyi öngörür. Bu öngörüye göre, Tanrı'nın aktif olarak kontrol ettiği bu gelişim sürecinde hem insan, hem kozmos hem de tarihte değişmeler ve gelişmeler olmaktadır. Kozmosun, şu halini almadan önce yer ve göğün bitişik olmas135; (insana ruhun üflenmesi, emanetin verilmesi, cennetten kovulması gibi mecazi ifadelerde görüldüğü gibi) insanın doğaya bağlı ve bağımlı (hominitas) bir varlıktan insani niteliklerinin tebarüz ettiği bir aşamaya (hümanitas) yükseltilmesi gibi, tarihte de, tarihin temel niteliği olan 'ilişkiler' de de bir evrilme ve tekamül söz konusudur. Bu evrilme sürecinde 'hürriyet' ve 'adalet' düşüncesinin insanın ve ilişkilerinin temel belirleyeni olarak ortaya çıktığını söylemek mümkündür. Yeni doğan bir bebeğin gelişim evreleri sürecinde anne-babasına bağımlılığının gittikçe yerini kendi kendine işlerini görme hürriyetine bırakması gibi, insan, kozmos ve bunların anlatısı durumundaki tarihte de benzer bir gelişimi görmek mümkündür. Bu evrilme ve gelişme, nasıl çocuğun anne-babasıyla olan evlatlık ilişkisini hiçbir zaman bitirmiyorsa, insanın ve kozmosun bu gelişimi Allah'la olan ilişkisini asla yitirmez, ancak bu ilişki nitelik değiştirir.

Allah'ın insanlarla ilişki tarihini yazılı olarak takip etmemize imkan veren Kutsal metinlere baktığımızda, bu ilişkiyi resmeden dilin ve insanlar arasındaki ilişkilerin temel sistematiğini oluşturan hitabın ve normların somuttan soyuta doğru gelişip, evrildiğini, Tanrı'nın ilk insanlara hitabının daha detaylı ve anlaşılmayı kolaylaştıracak tekrarlara sahipken, bu özelliğin Yeni Ahit'te ve Kur'an'da terkedildiğini görürüz.

Allah-insan arasındaki ilişkinin tarihine göz atıldığında bu ilişkinin omurgasını oluşturan iki temel ayağın varlı̆̆ı tespit edilebilir:

a. Tarihte yer tutmanın temel belirleyeni olan "misak/ahd/pakt",

b. Misak'ı ayak tutan ve geçerliliğini sağlayan 'normlar' ve 'uygulamaları' (şir'a/şeriat ve minhac)

\section{a. Tarihte Yer Tutmanın Temel Belirleyeni Olarak Misak/Ahd/Pakt}

Misak, hem bireysel hem de toplumsal bir boyuta sahiptir. Bireysel olarak nasıl bir anlam taşıdığını, insan prototipi durumundaki Adem'le Allah arasındaki ilişkiyi başından sonuna kadar takip ettiğimizde görürüz. Bu ilişki- 
de günah da, tövbe de bireyseldir." Aslında temiz bir fitratla yaratılan insan varlığın tek başına bulunduğu, ilişkili olduğu bir varlık alanının ve insanların bulunmadığı durumdaki saf halinin, büyüyüp gelişmesiyle nasıl ihtiraslı/muktedir olmayı arzulayan/muhteris bir insan karakterine dönüştüğünü ve bu saflık ve ihtiras yahut iktidar/tahakküm diyalektiğinin de tarihin seyrine yön verdiğini görürüz.

Misak/ahd kavramının toplumsal bir boyut kazanması Nuh (a.s.) ile başlamaktadır. "Nuhkavmini de peygamberi yalanladıkları zaman suda boğduk ve insanlara bir ibret yaptık"36 ve "Nuh'tan sonra nice kavimleri yok ettik" ${ }^{37}$ ayetlerinde işaret edildiği gibi, bu dönemde artık mesajın kabulü veya reddi toplu halde kurtarılmayı yada toplu halde yok edilmeyi gerektirmektedir.

Bu Misak'a aykırı davranmakla artık fısk (fasıklık), zulüm, zulmün toplumsal boyut kazanması anlamında tuğyan gibi kavramlar da tarih sahnesine çıkmaya başladı. Farklı toplum yada milletlerin varlığı, gelişmenin ve ilerlemenin temel güdenlerinden olan "mücadele" ve "çatışma" kavramlarına hayat verdi. Bu mücadelenin yada çatışmanın temeli aslında insanın yapisında varolan hükmetme/iktidar olma tutkusunun başkalarıyla da paylaşılıp yaygınlaştırılmasından başka bir şey değildir. Çatışmanın kaynağı ekonomik olduğu kadar (Marksist tarih yorumu) ideolojiktir de (Hegelci tarih yorumu). Sosyal olayların sebeplerini teke indirmenin zorluğu burada da karşımıza çıkar ve bunlardan birini tek bir belirleyen olarak almak yanlış değerlendirmelere götürebilir.

\section{b. Misak'ı ayak tutan ve geçerliliğini sağlayan 'normlar' ve 'uygulamaları' (şeriat ve minhac)}

Her topluluğun karakterine uygun düzenlemelerle tarihin devinimi ve gelişimi sağlanmıştır. “...sana gelen hak'tan ayrılıp da onların arzularına uyma. Sizden herbiriniz için bir şeriat ve bir yol koyduk"38 ayetinde anılan şeriat/şir'a ve minhac kavramları bu konuda bize yol göstermektedir. Şir'a (procède) ve minhac (method), heva ve hevesin alternatifi olarak ortaya

* İsrailoğulları tövbenin hiçbir zaman bağışlanma sebebi olamayacağını iddia ediyorlardı ve tabii ki buna göre de hem muamele ediyor hem de muamele görüyorlardı. Hezekiel zamanında Tanrı tövbe eden insanları cezalandırmaması sebebiyle protesto edilmişti (Hezekiel 18:25). İsrailliler, Tanrı'nın yolu adil bir yol değil, diyorlardı. Tanrı da, adil olmayan sizin tuttuğunuz yol değil midir? diye onları cevaplıyordu (Hezekiel 18: 27-29).

36 Furkân 25/37.

37 İsrâ 17/17.

38 Mâide 5/48. 
konulmaktadır. Bütün insanları tarih sahnesine tek tip bir millet olarak çıkarmak yerine, bir tekamül serisini tamamlayacak şekilde farklı milletler ve bunların karakterlerine uygun farklı şeriat ve minhacdan bahsedilmektedir. Şeriat'ın ve bunu uygulama yöntemi durumundaki minhac'ın somut bir anlayıştan soyuta doğru nasıl evrildiğini görmek için Kitab-ı Mukaddes'ten Allah ile İsrailoğulları arasındaki ilişkiyi takip etmek yeterlidir. ${ }^{39}$

- Davranışlara yön veren genel ahlaki ilkelerin ve bir 'adalet ahlakı'nın varolabileceğine dair bir düşünceden önce insanlar, 'kendisine yapılana ayn1sıyla karşılık verme', mantı̆̆ına sahiptiler. İnsanlar arasındaki ilişkilerin normlara oturmadığı bu dönemde, bireysel misilleme söz konusu idi ve adaletin, kendisine yapılanın aynısının karşıdaki kişiye tatbikiyle sağlanacağına inanılıyordu. Bu anlayışın hakim olduğu aşamada idareci yönetme hakkını, düşmanlarına karşı kudretini gösterme ve intikam almakla ispat etmeye çalışır ve ceza tehdidi ve mükafat vadiyle yönetirdi. Merhamet, yahut cezalandırmama, bir ahlaki davranış ve erdem değil, zayıflık belirtisi olarak algılanırdı:

"Gazabımı onların üzerine göndereceğim, ve böylece benim Tanrı olduğumu bilecekler,... ."40

"Merhamet gösterme: cana can, dişe diş, ele el, ayağa ayak." ${ }^{41}$

İsrailoğulları'nın Tanrı'nın merhametini zafiyet göstergesi olarak almalarına ve bu bağlamda doğan problemlere Kitab-1 Mukaddes'te epeyce vurgu vardır. İlişkilerin kanun ve kuralların ötesine taşınıp, genel ahlaki ilkelere dair bir anlayışın geliştirilmeye çalışıldığı, Tanrı'nın sadece, iddia ettikleri gibi İsrailoğulları'nın Tanrısı değil, bütün insanların Tanrı'sı olduğu anlayışının yerleştirilmeye çalışıldığı ileri bir aşamada Tanrı'nın merhametinin İsrailoğulları tarafından sorgulandığı görülür: “Adalet Tanrı'sı nerede?” Tanriya ibadet etmek boşuna ..." ${ }^{42}$ Yeremya peygamber bile Tanr1'yı protesto etmişti: "Adaletin konusunda seninle konuşmak istiyorum. Neden kötü insanlar müreffeh olurlar?"43 Tanrı'nın cevabı manidardır: "Yeremya, bu senin anlayamayacağın kadar ileri bir aşamadır." ${ }^{4}$

39 Hem bir felsefeci hem de çocuk gelişimi ile ilgilenen bir ahlakçı olan Lawrence Kohlberg'in İsrailoğullarının durumunu bir çocuğun gelişim aşamalarına uygulaması için bkz.

Http://www.aggelia.com/htdocs/kohlberg.shtml

40 Hezekiel 6:12, 13.

41 Tesniye 19: 21.

42 Malaki 2: 17, 3: 14, 15.

43 Yeremya 12:1.

44 Yeremya 12:5. 
Tanrı'nın İsrail'e verdiği on emir İsrailoğulları'ndaki bu somut zihnin ve somuta olan eğilimin bir göstergesidir. On emirde kıskanç, kızgın, ceza tehdidinde bulunan bir idareci izlenimi vardır. Tanrı, atalarının yaptıklarından dolayı çocuklarını suçlayan bir yönetici gibi sunulur. Bu durum, o dönemin davranış standartları (uyulması gereken ahlaki kuralların belirlenmediği bir dönem için) pek de problem yaratmaz. ${ }^{45}$ Sebep-sonuç zincirine alışık olan günümüz insanı için bu durum sorun yaratır, ama böyle bir kavrama sahip olmayanlar için bunun sorun yaratmamış olduğu görülüyor. Çocukların günahlarından dolayı babalarını cezalandırma İsrail döneminde çok sık görülen bir olgu olarak sunulmaktadır. Fakir, hasta, düşkün, vs bir insan görüldüğünde, kim günah işledi, bu adam mı ana-babası $\mathrm{m}$ ? diye sorulurdu. İsa fakirlere, mazlumlara, vs. iyi davrandığ 1 zaman, itiraz görüyordu; zira İsrailliler bunların günahlarından dolayı bu durumda bulunduklarına inanıyorlardı. Zengin olanların, Allah indinde de iyi oldukları kanaati vardı. Daha sonraki aşamada bu inanç düzeltildi ve "Çocuklarından dolayı babalar, babalarından dolayı da çocuklar artık öldürülmeyecekler; kendi günahından dolayı ancak kişinin kendisi ölümle cezalandırılacaktır" ilkesi yerleştirildi. Ancak bunu İsrailoğullarına anlatmak için epey dil döküldüğü görülür. ${ }^{46}$

Bu evre, insanların ilkelerden genel uygulamalar çıkaramadıkları bir evredir. Kurallar çok somut olarak algılandıkları için, detaylı bir şekilde açıklanmaları gerekmiştir. Bunun bir örneği, 10 emrin 2., 4. ve özellikle de 10. maddelerinde görülebilir. Tanrı İsraillilere komşularının evine göz dikmemelerini söyledikten sonra, komşunun sahip olduğu diğer unsurlara da ayrı ayrı dikkat çekmek durumunda kalmıştır: "Komşunun eşine, uşağına" eklemeleri de yapılmıştır. Emir burada durmuş olsaydı, komşunun diğer malları dahil edilmediği için onlara göz dikilebileceği sonucu çıkarılabilirdi. Bunun için de emrin devamında, "komşunun öküzüne, eşeğine" ilavesi yapılmıştır. Bunların dışındakilere yan gözle bakmanın serbest bırakıldığı anlaşılabilir diye, takiben "komşuya ait olan hiç bir şeye göz dikmeyeceksin" emri genelleme olarak verilmek durumunda kalınmıştır.

- Uyulacak toplu kuralların söz konusu olduğu bir sonraki aşamada, kişiler arası uygunluk ilkesinin hakim olduğunu görürüz: Bu aşamada doğru, içinde yaşanılan toplumun ve insanların beklentilerine ve davranışlarına uygunlukla belirlenir. Bireysel eylemler, başkalarının onayını almak için ya-

45 Çıkış 20: 5.

46 Hezekiel bölüm 18 ve Yeremya 31: 29-30. 
pılır. İyi davranış, başkalarını memnun eden, grup tatminine yönelik davranış olarak görülür. "Herkes öyle yapmaktadır." Bu davranış tekdüzeliği saygınlığı ve iyi olarak adlandırılmayı getirmektedir.Günah, toplumun beklentilerinin tersine hareket etmektir. Bu aşamada misilleme bireysel değil, kolektiftir.

İnsanların kendi geleneksel/konvansiyonel ahlak anlayışları içinde fakirleri aldatarak, güçsüzleri istismar ederek rahat bir yaşam sürdüklerini ve bunu çok normal bir durum olarak algılandığını görürüz. Zira bunu herkes yapıyordu ve herkesin yaptığı şey, genel kabul gören gelenekselleşmiş bir ahlak yasasına dönüşmüştü. Bu aşamada, insanların, Tanrı tarafından istenmediği halde bir çok ibadet ve tören icat ettiklerine ve bunlarla kanuna ne kadar bağlı olduklarını göstermek istediklerine şahit oluruz. Peygamber Amos aracılığıyla Tanrı onlara şöyle seslenir:

"Sizin dini festivallerinizden nefret ediyorum. Bu toplanmalarınıza tahammül edemiyorum... birakın adalet bir ırmak gibi ve fazilet de asla kurumayan bir dere gibi aksın." ${ }^{47}$

Tanrı onları sadece yazılı olana değil, kanun'un kalbine, mantı̆̆ına yönlendirmek istiyordu. Onlara "adil davranmanın ve merhameti sevmenin" kendisine "binlerce ya ̆̆ ırmağıyla, binlerce koç sunulmasından çok daha anlamlı olduğunu" söylüyordu. ${ }^{48}$

Bunu takip eden aşamada kurallara,kanunlara ve otoriteye saygı kavramı; sosyal ve kurumsal düzen ve toplumdaki diğer insanların haklarına karşı sorumluluk düşüncesi gelişir. "Adalet" bu aşamada da, kriminal ve mahkemede sağlanan adalet çerçevesinde tanımlanır. Adaletsizlik ise, kanunlara uyanları mükafatlandıramama, uymayanları cezalandıramama olarak anlaşılır. Bu aşamalarda henüz toplum içindeki ilişkileri belirlemenin sadece yasa ve kanunlara değil de, yazılı olmasa bile genel ahlaki ilkelere dayanabileceğine dair düşünce gelişmemiştir. Böyle bir anlayışın geliştiği bir sonraki ilişkiler ahlakında, sergilenen eylemin mevcut uygulamalara ve kanunlara uyup uymadığına değil, bazı temel evrensel, soyut ahlaki ilkelere uygun olup olmadığına bakılarak değerlendirilir. Bu aşamada bireyler, toplumdan önce gelen ve toplum tarafından korunması gereken haklara sahiptirler.

- Tanrı 1. evredeki kana dayalı öç almaları yumuşatmak ve 'adalet' kavramının anlaşılmasında değişiklik yaratmak ve bir üst aşamaya geçilmesini

47 Amos 5: 21, 24.

48 Mika 6: 6-8. 
sağlamak için hazırlık yapmış ve İsrailoğulları'na, kazara birisini öldüren kişinin kaçıp sığınacağı "sığınma şehirleri" yapmalarını emretmiştir. ${ }^{49}$ İnsanların bir eylemde bulunurken, bir 'niyet' yahut 'kastt' taşıyıp taşımadıkları ilk kez bu aşamada dikkate alınmaktadır. Bu sığınma şehirlerinin oluşturulması yönündeki emirden önce, insanlar ister kasten isterse kazaen bir günah veya suç işlediklerinde hemen cezalandırılma yoluna gidilirdi. Adalet anlayışının biraz daha geliştiği bu aşamada, artık 'niyet' unsuru ciddi anlamda adalet kavramının yanına eklemlenmiş görünmektedir. Düşmana merhamet göstermek, öldürmüş bile olsa bağışlamanın imkanından bahsetmek için insanın ve insan ilişkilerini tanımlayan kavramların daha fazla gelişme göstermesi gerekmekteydi. Bunun örneklerini görmek için Yeni Ahit'in ve Kur'an'ın cezalandırma felsefesine bakmak yeterlidir."

Tarihin ve zamanın nasıllığına bu müdahale, insan doğasının değişmezliği ve insan hayatının çeşitli aşamalar boyunca tekbiçimliliğini koruduğu yönündeki eski varsayıma artık başvuramayacağımız anlamına gelir. Tarih hem insan doğasını hem de insani toplumsal hayatın biçimlerini ve insanlar arasındaki ilişkinin niteliğini değiştirir. Zaman içinde ne kadar geç bir noktada yer alınıyorsa, değişim oranı o kadar büyüktür. İnsanlık tarihinin en yaşlıları olan ve kendilerine kadar geçen bütün bir insanlığın tecrübesini devralan günümüz insanının durduğu yer, bütün özellikleriyle kendisinden binlerce yıl önce geçmiş insanlardan tabii ki farklıdır. Ancak bu farklılığın iyi yönde mi yoksa, kötü yönde mi bir farklılaşma olduğuna verilecek cevap, aynı zamanda gelecek projeksiyonumuzla ilgili olacaktır. Bu da, fiten edebiyatı ve apokaliptik geleneği tersine çevirmeyi ve bir ümit teolojisi geliştirmeyi zorunlu hale getirmektedir.

Bu projeksiyonlara bakıldığında, Hıristiyanlıktaki apokaliptik kurgu, tarihi sonuçta iyimserlik vurgulanmış olmasına rağmen, kötümser bir akışa bırakmaktadır. Bu muhteşem güzelliğin, Tanrı'nın krallığının gerçekleşmesi için bir çok felaketin yaşanması gerektiği zihinlere kodlanmakta, sürekli kötüye giden bir süreç resmedilerek, iyimser bir gelecek fikri sakatlanmaktadır. Dünyanın kötüye gittiğini Kutsal Kitabın imparatorlukları simgelediği metallerde görmek mümkün: Babil kralı Nabukadnezzar'ın imparatorluğu altınla (Danyel 2:38, Medyen imparatorluğu, onun bir altında gümüşle (2:

49 Tesniye 19: 6.

* Levililer 20'de zinaya recm cezası uygulandı̆̆ını görüyoruz. İsa ise zina suçuyla yakalanan kadını bağışlamıştır. Kur'an, öldürülen kişinin mirasçılarına katili affetme yetkisi vermiş; Hz. Muhammed, zina fiilini işlediğini ve cezalandırılarak temizlenmek istediğini defalarca söyleyen kadını cezalandırmamıştır. Bunun örnekleri çoğaltılabilir. 
39), Pers imparatorluğu pirinçle (2: 39) ve Yunan kısmen demir, kısmen de kil toprakla (2:40) simgelenmektedir. ${ }^{50}$ İmparatorlukların oluşmuş olduklarının varsayıldığı bu metallerin değer kaybı, gittikçe imparatorluklara hayvani ve vahşi bir nitelik vermektedir; diğerlerinde olmayan bu vahşilik dördüncü imparatorlukta çok daha fazla gözlenmektedir. ${ }^{51}$

İslam'da da dünyanın sonuyla ilgili fiten edebiyat kurgusu bundan daha farklı değildir. İlerleyen tarihi süreç içerisinde toplumların geçirecekleri dejenarasyon, içine düşecekleri kaos, vs. meydana gelmesi kaçınılmaz birer kıyamet alameti olarak aktarılmıştır. Oysa bunların birer öngörüyle insanlara haber verilmesi, bunların kaçınılabilir olduğunu ve meydana gelmelerini engelleyici tedbirlerin alınabileceğini ima eder. Bu da geleceği zorunlu olarak kötüye kodlamanın gerekmediği gibi bir sonuç doğurur.

Öte yandan, İslam düşüncesinde, ilk çağlardan gittikçe uzaklaşma, faziletlerin ve değerlerin kaynağından, asr-1 saadetten (mutluluk çağı) de uzaklaşma olarak görülmüş ve gelecek beklentisi, asr-1 saadet adı altında geçmişe kodlanmıştır. Oysa asr-1 saadet, varılacak bir tavan/hedef değil, varılacak hedeflerin nüvesini ve dinamiklerini içinde barındıran bir taban/zemin olarak alınmalıdır.

\section{Sonuç}

Tanrı'nın evreni yaratmasındaki gai sebep insanlıktır. Tartışmasız, yaptığı her şeyi bir hikmete/gayeye göre düzenleyen Yaratıcı, bu gayesini gerçekleştirecek bilgi, irade ve kudret, vs. sıfatlara sahiptir. Aynı şekilde, evrende etkin ve yetkin güç (halife) olmasını irade ettiği insanı da, önüne koyduğu gayeleri gerçekleştirmesini sağlayacak benzer niteliklerle donatmıştır. Bu donanım, insanın hem ontik/fitri hem de epistemik/bilgisel yapısında mevcuttur.

İnsanın yetkin kılınmasına imkan veren terim ve kavramları Kur'an'la temellendirmeye çalışmamızın ana mantığı şudur: dünyada olup biten her şey nihayetinde insanı ilgilendirmektedir. Hüzünlenen de, sevinen de odur. İnsanın yaşadığı bu halleri tanımlama, belirleme, bunlarla ilgili değerler oluşturma da en temel insan hakkı olarak görülmelidir. Bununla birlikte, Kutsal Kitap geleneklerine bağlı olan topluluklar, söyledikleri her sözün ilahi olan için bir tehdit oluşturup oluşturmadığı noktasında ifrata varan bir tedirginliği kurumsallaştırmış bulunmaktadırlar. Oysa Allah delile ve bürha-

50 Christopher North, The Old Testament Interpretationof History, Londra, 1953, s. 137.

51 Daniel 7: 7. 
na dayanan ve hakkı dikkate alan her türlü üretimi, bırakınız hoş karşılamayı, teşvik etmektedir. Bu yazı, bu teşvikin anlamlı bir eylemler bütününü yaratabilmesi için insanın Tanrı tarafından hangi ontik ve epistemik yeteneklerle donatıldığını ortaya koyarak, insana açılan sorumluluk alanının aktüel bir değer kazanmasını sağlamayı hedeflemektedir. 